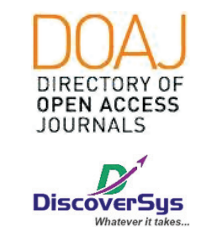

Published by DiscoverSys

\section{Korelasi antara parameter faal hemostasis dan kadar serum laktat sebagai indikator mortalitas pada pasien multiple trauma di Rumah Sakit Umum Pusat Sanglah Denpasar, Bali-Indonesia}

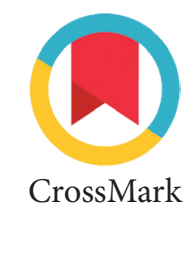

\author{
Hizkia Robinson Junsen Lumban Gaol, ${ }^{1 *}$ Ketut Wiargitha, ${ }^{2}$ Gde Raka Widiana ${ }^{3}$
}

\title{
ABSTRACT
}

Background: Trauma is now the most frequent cause of death in the first four decades of life and is still a major public health problem in every country. Trauma that occurs often involves several regions of the body. This condition is called multiple trauma. In multiple trauma, coagulopathy often occurs. In the last four decades it was mentioned that in multiple trauma conditions also occur acidosis and coagulopathy which will also increase the mortality of multiple trauma patients with multiple trauma, serum lactate is superior to base deficit. The purpose of this study is to obtain the correlation of each prothrombin time (PT) value, activated partial prothrombin time (aPTT) value and international normalized ratio (INR) value with serum lactate levels as indicators of mortality in multiple trauma cases.

\begin{abstract}
Methods: This study was an observational study with an analytic crosssectional design to determine the correlation between physiological parameters of hemostasis and serum lactate in multiple trauma patients. Results: From the 60 samples studied there were 43 male patients (71.7\%) and 17 female patients (28.3\%) with an average age of $37 \pm$ 19.61 years. 7 (11.7\%) cases died. Logistic regression test with each conducted on the APPT and INR variables and lactate levels obtained aPTT was the most influential risk factor for mortality with a $\mathrm{p}$-value of $0.005<0.05$ OR 0.023 (Cl 95\%: 0.002-0.332)

Conclusion: Serum lactate levels and physiological hemostasis are not only indicators that explain a patient in a state of shock, but can also be used as an indicator in determining morbidity and mortality in multiple trauma patients.
\end{abstract}

Keywords: multiple trauma, serum lactate, physiological hemostasis, morbidity, mortality.

Cite This Article: Gaol, H.R.J.L., Wiargitha, K., Widiana, G.R. 2020. Korelasi antara parameter faal hemostasis dan kadar serum laktat sebagai indikator mortalitas pada pasien multiple trauma di Rumah Sakit Umum Pusat Sanglah Denpasar, Bali-Indonesia. Intisari Sains Medis 11(2): 429-433. D0I: 10.15562/ism.v11i2.726

1PPDS-1 IImu Bedah, Fakultas Kedokteran, Universitas UdayanaRSUP Sanglah Denpasar, BaliIndonesia

${ }^{2}$ Divisi Bedah Taruma, Departemen/KSM IImu Bedah, Fakultas Kedokteran Universitas Udayana-RSUP Sanglah Denpasar, Bali-Indonesia

${ }^{3}$ Divisi Ginjal dan Hipertensi, Departemen/KSM IImu Penyakit Dalam, Fakultas Kedokteran Universitas Udayana-RSUP Sanglah Denpasar, Bali-Indonesia

*Correspondence to:

Hizkia Robinson Junsen Lumban Gaol, PPDS-1 IImu Bedah, Fakultas

Kedokteran, Universitas Udayana-

RSUP Sanglah Denpasar, Bali-

Indonesia

baptista.hizkia007@gmail.com

Diterima: 05-03-2019

Disetujui: 08-06-2020

Diterbitkan: 17-06-2020

\section{ABSTRAK}

Latar belakang: Trauma saat ini merupakan penyebab kematian paling sering dalam empat dekade pertama kehidupan dan masih menjadi masalah kesehatan masyarakat yang utama di setiap negara. Trauma yang terjadi seringkali melibatkan beberapa regio tubuh. Kondisi ini disebut dengan multipel trauma. Pada multipel trauma, sering terjadi koagulopati. Pada empat decade terakhir disebutkan bahwa pada multipel trauma juga terjadi keadaan asidosis serta koagulopati yang juga akan meningkatkan mortalitas pasien multipel trauma multipel trauma, serum laktat lebih superior dibanding defisit basa. Tujuan dari penelitian ini adalah didapatkan korelasi masing - masing nilai prothrombin time (PT), nilai activated partial prothrombin time (aPTT) dan nilai international normalized ratio (INR) dengan kadar serum laktat sebagai indikator mortalitas pada kasus multipel trauma.
Metode: Penelitian ini merupakan studi observasional dengan rancangan potong lintang analitik untuk mengetahui korelasi antara parameter faal hemostasis dan serum laktat pada pasien multiple trauma.

Hasil: Dari 60 sampel yang diteliti dijumpai penderita laki-laki sebanyak 43 orang $(71,7 \%)$ dan perempuan 17 orang $(28,3 \%)$ dengan rata-rata usia $37 \pm 19,61$ tahun. Penderita yang meninggal sebanyak $7(11,7 \%)$ kasus. Uji regresi logistik dengan masing masing dilakukan pada variabel APPT dan INR serta kadar laktat didapatkan aPTT merupakan faktor risiko yang paling berpengaruh terhadap terjadinya mortalitas dengan $\mathrm{p}$-value $0,005<0,05$ OR 0,023 (IK: 0,002-0,322)

Simpulan: Kadar serum laktat dan faal hemostasis tidak hanya sebagai indikator yang menerangkan pasien dalam keadaan syok, tapi juga dapat digunakan sebagai indikator dalam menentukan morbiditas dan mortalitas pada pasien multipel trauma.
Kata kunci: Multipel trauma, serum laktat, faal hemostasis, morbiditas, mortalitas.

Cite Pasal Ini: Gaol, H.R.J.L., Wiargitha, K., Widiana, G.R. 2020. Korelasi antara parameter faal hemostasis dan kadar serum laktat sebagai indikator mortalitas pada pasien multiple trauma di Rumah Sakit Umum Pusat Sanglah Denpasar, Bali-Indonesia. Intisari Sains Medis 11(2): 429-433. DOI: 10.15562/ism.v11i2.726 


\section{PENDAHULUAN}

Trauma saat ini merupakan penyebab kematian paling sering dalam empat dekade pertama kehidupan dan masih menjadi masalah kesehatan masyarakat yang utama di setiap negara. ${ }^{1}$ Data WHO (World Health Organization) menyebutkan sebanyak 5,6 juta orang meninggal dan sekitar 1,3 juta orang mengalami cacat fisik akibat kecelakaan lalu lintas di seluruh dunia selama tahun 2011. Data dari Kepolisian Republik Indonesia tahun 2017 menyebutkan pada tahun 2015 terjadi 38.279 kasus kecelakaan di jalan raya dengan korban terbanyak berusia 15-55 tahun. Trauma yang terjadi seringkali melibatkan beberapa regio tubuh. Kondisi ini disebut dengan multipel trauma. Pada multipel trauma, sering terjadi koagulopati. Dimana koagulopati itu diantaranya berasal dari perdarahan, baik dari mukosa, permukaan serosa dan akses pembuluh darah yang pada akhirnya akan mengakibatkan kematian. ${ }^{2}$ Pada empat decade terakhir disebutkan bahwa pada multipel trauma juga terjadi keadaan asidosis serta koagulopati yang juga akan meningkatkan mortalitas pasien multipel trauma. ${ }^{3}$

Saat ini penelitian untuk mencari marker yang terbaik untuk diagnosis, prognosis, dan penanganan pasien-pasien trauma masih terus berlangsung. Pedoman untuk akhir dari resusitasi masih menjadi kontroversi. Idealnya, suatu marker harus mampu menilai resusitasi yang adekuat, menilai hipoksia jaringan serta mampu memprediksi mortalitas dan hasil akhir dari pasien-pasien trauma. Secara umum, resusitasi pada kasus trauma dan tindakan operasi emergensi didasarkan pada kombinasi dari nilai laboratorium, tanda vital, dan keadaan klinis.

Pasien trauma berat dengan tekanan darah yang normal, dan urin output yang cukup, tapi masih dalam keadaan shock yang terkompensasi. Sehingga diperlukan marker lain. Dua marker yang sering digunakan untuk menilai keberhasilan resusitasi adalah koagulopati dan kadar serum laktat. $^{4}$

Koagulopati adalah suatu kondisi terganggunya kemampuan darah mengadakan pembentukan clot (bekuan). ${ }^{5}$ Koagulasi akut telah diteliti terdapat pada satu dari empat pasien trauma dan menyebabkan peningkangkatan mortalitas empatkali lebih besar. Koagulopati yang terjadi pada pasien trauma dipicuoleh perdarahan masif, hemodilusi, hipotermia dan asidosis. Proses ini menyebabkan 6 faktor pemicu terjadinya koagulopati yaitu hipoperfusi jaringan, trauma jaringan, hipotermia, asidosis, hemodilusi dan inflamasi. Hasil akhir dari keseluruhan patofisiologis ini disebut trias kematian pada trauma, yaitu hipotermia, asidosis dan koagulopati. Penatalaksanaan trias kematian ini terfokus pada pencegahan hipotermia dan asidosis tanpa intervensi koagulopati. Hal ini disebabkan karena koagulopati merupakan factor prognosis bebas yang merupakan tujuan utama yang harus dicegah pada damage control resuscitation. ${ }^{7}$

Penelitian yang dilakukan terdahulu menunjukkan kejadian koagulopati pada pasien multipel trauma berkisar antara $10-34 \% .4,7,8$ Penelitian tersebut juga menunjukkan koagulopati dapat menjadi indikator dalam menentukan angka mortalitas pada pasien multipel trauma.

Di lain pihak, terdapat biomarker lain yang berhubungan erat dengan mortalitas terhadap pasien yang mengalami disfungsi organ dan syok, yaitu serum laktat. Serum laktat adalah parameter yang sensitif untuk menilai adekuat-tidaknya oksigenasi sel. Serum laktat adalah produk akhir dari metabolism anaerob dan marker spesifik untuk hipoksia jaringan. Peningkatan tingkat laktat mencerminkan hipoksia jaringan dan metabolisme anaerobik berlangsung dalam tubuh. ${ }^{3}$ Akan tetapi belum ada data yang jelas mengenai koagulopati pada pasien multiple trauma dan hubungan antara koagulopati dan kadar serum laktat sebagai indikator mortalitas pada pasien multipel trauma. Tujuan dari penelitian ini adalah untuk mengkaji hubungan nilai faal hemostasis dan kadar serum laktat sebagai salah satu indikator untuk menilai mortalitas pasien multipel trauma di RSUP Sanglah.

\section{METODE}

Penelitian ini merupakan studi observasional dengan rancangan potong lintang analitik untuk mengetahui korelasi antara parameter faal hemostasis dan serum laktat pada pasien multiple trauma. Penelitian dilaksanakan di Instalasi Gawat Darurat Rumah Sakit Umum Pusat Sanglah Bali. Populasi target adalah pasien dengan multipel trauma dengan skor ISS $\geq 9$ yang datang ke instalasi gawat darurat RSUP Sanglah Bali. Kriteria inklusi dalam penelitian ini adalah durasi trauma kurang dari 12 jam sebelum masuk rumah sakit, dan bersedia menjadi sampel dalam penelitian setelah mendapat inform consent dari keluarga. Kriteria eksklusi dalam penelitian ini adalah pasien meninggal sebelum resusitasi. Evaluasi fungsi koagulasi yang menjadi focus adalah nilai PT, aPTT, dan INR. Kemudian serum laktat digunakan sebagai penanda asidosis. Parameter tersebut akan digunakan sebagai predictor dari mortalitas pasien dengan trauma multipel. Analisis data dalam penelitian ini menggunakan bantuan SPSS versi 25.0, uji chi-square dan analisis risiko digunakan untuk mencari hubungan faktor risiko dari variabel bebas 
terhadap mortalitas pada pasien multipel trauma, kemudian regresi logistic digunakan untuk mengkaji faktor risiko yang paling berperan terhadap terjadinya mortalitas pada pasien dengan multipel trauma.

\section{HASIL}

Penelitian ini melibatkan 60 responden, karakteristik dari sampel penelitian dapat dilihat pada tabel 1. Karakteristik berdasarkan umur responden dengan rata-rata 37 tahun SD 19,61. Karakteristik berdasarkan jenis kelamin didapatkan data lakilaki lebih banyak yaitu 43 responden $(71,7 \%)$ dibandingkan perempuan 17 responden (28,3\%). Karakteristik berdasarkan nilai PT > 15 detik sebanyak 17 responden $(28,3 \%)$ dan PT $\leq 15$ detik sebanyak 43 responden (71,7\%). Karakteristik berdasarkan aPTT $>40$ detik sebanyak 8 responden $(13,3 \%)$ dan aPTT $\leq 40$ detik sebanyak 52 responden $(86,7 \%)$. Karakteristik berdasarkan INR > 1,2 sebanyak 12 responden (20\%) dan INR $\leq 1,2$ sebanyak 48 responden $(80 \%)$. Karakteristik berdasarkan kadar laktat didapatkan kadar laktat > 2,2 $\mathrm{mmmol} / \mathrm{L}$ sebanyak 19 responden $(31,6 \%)$ dan kadar laktat $\leq 2,2 \mathrm{mmol} / \mathrm{L}$ sebanyak 41 responden $(68,4 \%)$. Karakteristik berdasarkan mortalitas pasien trauma didapatkan meninggal

Tabel 1 Karakteristik responden berdasarkan umur jenis kelamin kadar PT aPTT INR serum laktat dan mortalitas pasien

\begin{tabular}{lc}
\hline Variabel & $\mathbf{n}=\mathbf{6 0}$ \\
\hline Umur (mean,SD) & $37 \pm 19,61$ \\
Jenis kelamin & \\
$\quad$ Laki-laki & $43(71,7 \%)$ \\
$\quad$ Perempuan & $17(28,3 \%)$ \\
Nilai PT & \\
$\quad>15$ detik & $17(28,3 \%)$ \\
$\quad \leq 15$ detik & $43(71,7 \%)$ \\
Nilai aPTT & \\
$\quad>40$ detik & $8(13,3 \%)$ \\
$\quad \leq 40$ detik & $52(86,7 \%)$ \\
INR & \\
$>1,2$ & $12(20 \%)$ \\
$\quad \leq 1,2$ & $48(80 \%)$ \\
Kadar serum laktat & \\
$\quad>2,2$ mmol/L & $19(31,6 \%)$ \\
$\quad \leq 2,2$ mmol/L & $41(68,4 \%)$ \\
Mortalitas & \\
$\quad$ Meninggal & $7(11,7 \%)$ \\
Hidup & $53(88,3 \%)$ \\
\hline
\end{tabular}

sebanyak 7 responden $(11,7 \%)$ dan hidup sebanyak 53 responden $(88,3 \%)$.

Kadar PT $>15$ detik dengan mortalitas pasien trauma meninggal sebanyak 5 responden $(29,4 \%)$ dan hidup sebanyak 12 responden (70,6\%) sedangkan kadar PT $\leq 15$ detik dengan mortalitas meninggal sebanyak 2 responden (4,7\%) dan hidup sebanyak 41 responden (95,3\%) dengn p-value $0,007<0,05$ yang berarti ada hubungan yang signifikan dari kadar PT dengan mortalitas pasien trauma. Nilai OR 8,5 (IK: 1,46-49,72) berarti nilai PPT $>15$ detik mempunyai peluang terjadi mortalitas meninggal pasien trauma sebanyak 8,5 kali (Tabel 2).

Kadar aPTT > 40 detik dengan mortalitas pasien trauma meninggal sebanyak 5 responden $(62,5 \%)$ dan hidup sebanyak 3 responden $(37,5 \%)$ sedangkan kadar aPTT $\leq 40$ detik dengan mortalitas meninggal sebanyak 2 responden $(3,8 \%)$ dan hidup sebanyak 50 responden $(96,2 \%)$ dengan p-value $0,000<0,05$ yang berarti ada hubungan yang signifikan dari kadar aPTT dengan mortalitas pasien trauma. Nilai OR 41,6 (IK: 5,57-311,4) berarti nilai aPTT $>40$ detik mempunyai peluang terjadi mortalitas meninggal pasien trauma sebanyak 41,6 kali (Tabel 2).

Data INR $>1,2$ dengan mortalitas pasien trauma meninggal sebanyak 5 responden $(41,7 \%)$ dan hidup sebanyak 7 responden $(58,3 \%)$ sedangkan INR $\leq 1,2$ dengan mortalitas meninggal sebanyak 2 responden (4,2\%) dan hidup sebanyak 50 responden $(95,8 \%)$ dengn p-value $0,000<0,05$ yang berarti ada hubungan yang signifikan antara nilai INR dengan mortalitas pasien trauma. Nilai OR 16,4 (IK:2,65-101,64) berarti nilai INR $>1,2$ mempunyai peluang terjadi mortalitas meninggal pasien trauma sebanyak 16,4 kali (Tabel 2).

Kadar laktat> 2,2 $\mathrm{mmol} / \mathrm{L}$ dengan mortalitas pasien trauma meninggal sebanyak 7 responden $(36,8 \%)$ dan hidup sebanyak 12 responden $(63,2 \%)$ sedangkan kadar laktat $\leq 2,2 \mathrm{mmol} / \mathrm{L}$ dengan mortalitas meninggal sebanyak 0 responden $(0 \%)$ dan hidup sebanyak 41 responden (100\%) dengan p-value $0,000<0,05$ yang berarti ada hubungan yang signifikan dari kadar laktat dengan mortalitas pasien trauma Nilai OR 0,63 (IK:0,44-0,89) berarti kadar laktat > 2,2 hanya mempunyai peluang terjadi mortalitas meninggal pasien trauma sebanyak 0,63 kali (Tabel 2).

Uji regresi logistik dengan masing masing dilakukan pada variabel APPT dan INR serta kadar laktat didapatkan aPTT merupakan faktor risiko yang paling berpengaruh terhadap terjadinya mortalitas dengan $\mathrm{p}$-value $0,005<0,05$ OR 0,023 (IK: 0,002-0,322) (Tabel 3). 
Tabel 2 Hubungan faal koagulasi dan serum laktat terhadap mortalitas pada pasien dengan multipel trauma

\begin{tabular}{|c|c|c|c|c|c|}
\hline \multirow[b]{2}{*}{ Variabel } & \multicolumn{2}{|c|}{ Mortalitas } & \multirow[b]{2}{*}{ OR } & \multirow[b]{2}{*}{ IK 95\% } & \multirow[b]{2}{*}{ p-value } \\
\hline & Meninggal & Hidup & & & \\
\hline \multicolumn{6}{|l|}{ Kadar aPTT } \\
\hline$>40$ detik & $5(62,5 \%)$ & $3(37,5 \%)$ & 41,6 & $5,57-311,4$ & 0,000 \\
\hline$\leq 40$ detik & $2(3,8 \%)$ & $50(96,2 \%)$ & & & \\
\hline \multicolumn{6}{|l|}{ INR } \\
\hline$>1,2$ & $5(41,7 \%)$ & $7(58,3 \%)$ & 16,4 & $2,65-101,64$ & 0,000 \\
\hline$\leq 1,2$ & $2(4,2 \%)$ & $50(95,8 \%)$ & & & \\
\hline \multicolumn{6}{|l|}{ Kadar laktat } \\
\hline$>2,2 \mathrm{mmol} / \mathrm{L}$ & $7(36,8 \%)$ & $12(63,2 \%)$ & 0,63 & $0,44-0,89$ & 0,000 \\
\hline$\leq 2,2 \mathrm{mmol} / \mathrm{L}$ & $0(0 \%)$ & $41(100 \%)$ & & & \\
\hline \multicolumn{6}{|l|}{ Kadar PT } \\
\hline$>15$ detik & $5(29,4 \%)$ & $12(70,6 \%)$ & 8,5 & $1,46-49,72$ & 0,007 \\
\hline$\leq 15$ detik & $2(4,7 \%)$ & $41(95,3 \%)$ & & & \\
\hline
\end{tabular}

Tabel 3 Model regresi logistik dari fungsi koagulasi dan asamlaktat terhadap mortalitas dari pasien dengan multipel trauma

\begin{tabular}{lcccc}
\hline Variabel & B & Exp (B) & IK 95\% & p-value \\
\hline PT & 1,429 & 0,240 & $0,015-3,851$ & 0,313 \\
aPTT & 3,791 & 0,023 & $0,002-0,322$ & 0,005 \\
INR & 2,064 & 0,127 & $0,009-1,81$ & 0,128 \\
Kadar laktat & 0,578 & 0,561 & $0,004-83,24$ & 0,821 \\
\hline
\end{tabular}

\section{PEMBAHASAN}

Multipel trauma atau politrauma adalah apabila terdapat 2 atau lebih kecederaan secara fisikal pada regio atau organ tertentu, dimana salah satunya bisa menyebabkan kematian dan memberi impak pada fisikal, kognitif, psikologik atau kelainan psikososial dan disabilitas fungsional. Trauma adalah penyebab paling umum kematian pada usia 15-44 tahun di seluruh dunia. Proporsi terbesar dari kematian (1,2 juta pertahun) kecelakaan di jalan. Organisasi Kesehatan Dunia (WHO) memprediksi bahwa pada tahun 2020, cederalalu lintas menduduki peringkatketiga dalam penyebab kematian dini dan kecacatan. Pada penelitian ini dijumpai 60 kasus multipel trauma yang datang ke instalasi gawat darurat Rumah Sakit Umum Pusat Sanglah,Bali, dengan rata-rata usia penderita multiple trauma adalah $37 \pm 19.61$ tahun, dengan jenis kelamin terbanyak pada penderita multipel trauma adalah laki-laki yaitu sebanyak 43 orang $(71,7 \%)$ dan perempuan 17 orang $(28,3 \%)$.

Tingkat mortalitas pada penderita multipel trauma sebesar 7 orang (11,7\%). Sedangkan berdasarkan penelitian yang dilakukan oleh Lamichane dkk pada tahun 2011, tingkat mortalitas pada pasien multipel trauma adalah $7,7 \%$. Peningkatan tingkat laktat mencerminkan hipoksia jaringan dan metabolisme anaerobik yang sedang berlangsung dalam tubuh dan biasanya diatasi dengan dengan resusitasi yang memadai. Peningkatan serum laktat yang menetap meskipun telah dilakukan resusitasi merupakan indikator bahwa sedang berlangsungnya keadaan shock pada tubuh atau resusitasinya tidak adekuat. Hal ini berhubungan dengan tingginya angka gagal nafas dan kematian. Serum laktat akan meningkat segera dalam tiga puluh menit setelah terjadinya trauma. ${ }^{9}$ Pada penelitian ini kadar serum laktat yang terbanyak adalah dengan nilai $>2,2$ yaitu 55 orang $(91,7 \%)$.

Ini menunjukkan bahwa pada sampel penelitian ini sebagian cedera yang dialami oleh pasien multipel trauma merupakan cedera yang berat atau keadaan pasien yang sedang dalam keadaan syok.. Pada penelitian ini, dari 60 sampel yang diteliti, dijumpai penderita yang meninggal sebanyak 7 (11,7\%)orang dan yang hidup sebanyak 53(83,3\%) orang. Dan dijumpai hubungan kadar serum laktat terhadap mortalitas. Pemeriksaan inisial asam laktat sangat berguna sebagai informasi 
dalam menentukan mortalitas pasien. Sehingga dokter yang bertugas di unit gawat darurat dapat memprediksi apakah pasien perlu dirawat di ICU atau ruangan. Selain itu Serum laktat inisial juga dapat dijadikan sebagai tambahan informasi dalam mengambil keputusan medis untuk meningkatkan hasil akhir pasien multipel trauma yang ditangani. ${ }^{8}$

Penelitian yang dilakukan oleh Macleod et al. menemukan bahwa kadar serum laktat $>2 \mathrm{mmol} /$ liter merupakan suatu yang abnormal dan kadar serum laktat $>5 \mathrm{mmol} /$ liter dianggap suatu nilai yang signifikan dalam menyebabkan morbiditas dan mortalitas. Beberapa penelitian telah menunjukkan pentingnya penilaian serum laktat, terutama setelah dilakukan resusitasi pada pasien-pasien kritis dan pasien multipel trauma. Abramson et al. telah meneliti 76 pasien multipel trauma dan dilakukan pengukuran serum laktat secara serial yaitu inisial, 24 jam, 48 jam dimana sebelumnya telah dilakukan resusitasi yang sesuai dengan protokol ATLS terlebih dahulu dan dijumpai 27 pasien survive bila serum laktat berhasil diturunkan menjadi $<2 \mathrm{mmol} /$ liter dalam 24 jam dan hanya 3 pasien yang survive dari 22 kasus(13,6\%) bila bersihan serum laktatnya tidak dapat diturunkan dalam 48 jam. ${ }^{4}$ Farah A. Husain et al. menyatakan bahwa angka survival pasien multipel trauma mencapai 90\% bila kadar serum laktat dapat diturunkan menjadi normal dalam waktu 24 jam, namun angka survivalnya menjadi 33\% bila kadar serum laktatnya tidak dapat diturunkan dalam 24 jam. Pada 60 sampel penelitian ini dijumpai hubungan nilai Faal hemostasis (PT, aPTT dan INR) terhadap mortalitas pasien multiple trauma, hal ini sesuai dengan penelitian yang dilakukan oleh Manuel Mutschler et al. bahwa nilai Faal Hemostasis terbukti sebagai salah satu prediktor terbaik dalam menentukan morbiditas dan mortalitas pada pasien multipel trauma. Hal ini juga sesuai dengan penelitian ini yaitu dari 60 sampel penelitian dijumpai kasus yang meninggal sebanyak 7 orang, dimana 5 orang $(71,42 \%)$ memiliki nilai PT, aPTT dan INR yang tinggi. Pada penelitian ini dijumpainya hubungan antara kadar serum laktat dan nilai faal hemostasis terhadap mortalitas yaitu hubungan korelasi sedang dimana jika semakin tinggi kadar serum laktat maka nilai nilai Faal hemostasis juga semakin tinggi terhadap mortalitas.

\section{SIMPULAN}

Terdapat hubungan yang bermakna antara kadar serum laktat, nilai PT, nilai aPTT, INR terhadap mortalitas. Serum laktat dan nilai faal hemostasis pada penelitian ini dapat dijadikan sebagai indikator dalam menentukan mortalitas pasien multiple trauma, maka sebaiknya pemeriksaan ini dapat diterapkan di instalasi gawat darurat Rumah Sakit Umum Pusat Sanglah, Bali. Dimana hal ini sudah menjadi protokol tetap di negara maju dalam menangani pasien multipel trauma.

\section{KONFLIK KEPENTINGAN}

Penulis menyatakan tidak terdapat konflik kepentingan terkait publikasi dari penelitian ini.

\section{ETIKA DALAM PENELITIAN}

Penelitian ini telah mendapat persetujuan dari Komite Etik Fakultas Kedokteran Universitas Udayana/RSUP Sanglah Denpasar dengan npmer eferensi 34/UN14.2.2.VII.14/LP/2019.

\section{PENDANAAN}

Penelitian ini tidak mendapatkan bantuan dana dari pemerintah ataupun lembaga swasta lainnya.

\section{DAFTAR PUSTAKA}

1. Davenport R, dkk. Functional Definition and Characterisation of Acute Traumatic Coagulopathy. Critical Care Medicine. 2011;39(12):2652-2658.

2. Spahn DR, Boillon B, Cerny V, Coats TJ, Duranteau J, Fernandez-Mondejar E, dkk. Management of bleeding and coagulopathy following major trauma: an update European guideline. Critical Care. 2013;17:R76-82.

3. Nardi G, dkk. Prevention and Treatment of Trauma Induce Coagulopathy: An Intended Protocol from the Italian Trauma Update Research Group. Journal of Anesthesiology and Science. 2013;12:2-22.

4. Macleod JB, et al. Early Coagulopathy Predicts Mortality in Trauma. Lippincott Williams and Willkins. 2003;55:1-8.

5. Davenport R, dkk. Functional Definition and Characterisation of Acute Traumatic Coagulopathy. Critical Care Medicine. 2011;39(12):2652-2658.

6. Anusha C, dkk. Acute coagulopathy of trauma: Mecanism, monitoring, management. World Journal Anesthesiology. 2014;3(1):111-118.

7. Brohi K, Cohen MJ, Davenprt RA. Acute Trauma Coagulopathy: Mecanism, Identification, and Effect. J Trauma Ivest. 2007;13:680-685.

8. Maegele M, dkk. The Acute Coagulopathy of Trauma: Mecanisms and Tools for Risk Stratification. Shock. 2012;38:12-19.

9. Abramson D, et al. Lactate clearance and survival following injury. J Trauma. 1993;35(2):584-588.

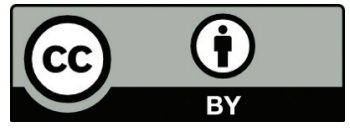

This work is licensed under a Creative Commons Attribution 